\title{
Harnessing Indigenous Technologies for Sustainable Management of Land, Water, and Food Resources Amidst Climate Change
}

\author{
Ziblim Abukari Imoro ${ }^{1 \dagger}$, Abubakari Zarouk Imoro ${ }^{2 * \dagger}$, Abudu Ballu Duwiejuah ${ }^{3 \dagger}$ and \\ Ammal Abukari ${ }^{4 \dagger}$ \\ ${ }^{1}$ Department of Biodiversity Conservation and Management, University for Development Studies, Tamale, Ghana, \\ ${ }^{2}$ Department of Environment, Water and Waste Engineering, University for Development Studies, Tamale, Ghana, \\ ${ }^{3}$ Department of Biotechnology, University for Development Studies, Tamale, Ghana, ${ }^{4}$ Department of Forestry and Forest \\ Resources Management, University for Development Studies, Tamale, Ghana
}

OPEN ACCESS

Edited by:

Felix Kwabena Donkor, University of South Africa, South Africa

Reviewed by:

Mohammed Jashimuddin University of Chittagong, Bangladesh Ajit Singh,

University of Nottingham Malaysia Campus, Malaysia

*Correspondence: Abubakari Zarouk Imoro zaroukimoro@yahoo.com

tThese authors have contributed equally to this work and share first authorship

Specialty section:

This article was submitted to Land, Livelihoods and Food Security, a section of the journal Frontiers in Sustainable Food Systems

Received: 06 April 2021

Accepted: 16 July 2021

Published: 12 August 2021

Citation:

Imoro $Z A$, Imoro $A Z$, Duwiejuah $A B$ and Abukari $A$ (2021) Harnessing

Indigenous Technologies for Sustainable Management of Land, Water, and Food Resources Amidst Climate Change.

Front. Sustain. Food Syst. 5:691603. doi: 10.3389/fsufs. 2021.691603
Through advancements in technology humans have cultivated more food, used more fossil fuel reserves, polluted the environment, and caused climate change. This was not the case some few decades ago where indigenous technologies were used in exploiting natural resources. Unfortunately, the effects of climate change on the planet are no more distant reality. The melting of glaciers, rising sea levels, extreme rainfall, and prolonged drought are already being experienced. These have affected water resources, land, and food security across the world. The limits of conventional climate change adaptation and mitigation strategies call for the integration of indigenous knowledge and technologies for tackling climate change issues. This is because of the importance that indigenous knowledge and technologies have for identifying the impacts and as well providing effective adaption and mitigation strategies to climate change. Thus, this chapter explores the potential of indigenous knowledge and technologies for the sustainable management of water, land, and food security amidst climate change. The applications of indigenous technologies and knowledge such as agroforestry, the use of sacred groves to conserve water, land, and biodiversity resources, and the practising of conservation-agriculture are discussed as solutions for reducing greenhouse gas emissions, water shortages, land degradation, and pollution. However, these indigenous technologies will be less useful in today's world if not harnessed. Thus also in this chapter, the scientific know-how available to improve the effectiveness of indigenous technologies for the sustainable use of water, land, and food resources have been identified (Robotics, sensors/detectors, internet of things) and discussed.

Keywords: indigenous, climate-change, mitigation, adaptation, sustainable-agriculture

\section{INTRODUCTION}

In this chapter, the authors explored the use of indigenous knowledge and technologies for the management of land, water, and food resources under changing weather conditions and the potentials of this knowledge/technology for climate change mitigation and adaptation. Climate change poses a major and growing threat to universal food security. The projected effects of climate change that include higher temperatures, water scarcities, 
land degradation, disruption of ecosystems, and the loss of biodiversity could seriously compromise agriculture's ability to feed the most vulnerable and thus impede progress towards the reduction or extermination of hunger, malnutrition, and poverty. Whilst water resources are already scarce and unsafe in some parts of the world, climate change is expected to increase the pressure on existing resources in the years to come. Climate variability and change have further exacerbated conflicts concerning access and ownership, and the use of natural resources.

Producing healthy food in a sustainable way to meet the needs of a growing world population is one of the major challenges of our time and climate change has exacerbated this. For instance by the year 2050, Sub-Saharan Africa will experience rainfall drop of about $10 \%$ and this will result in major shortages of water (Nyong, 2005) and food resources.To tackle this envisaged problem, a holistic approach to harness and diversify indigenous technologies/systems that allow for greater resilience to climate variability and change is recommended. Maintaining biodiversity for food and agriculture through the use of climate-smart-agroforestry systems is indispensable for adapting to climate change. Encouraging the conservation of genetic resources ex situ as well as in situ, especially on farms, and through conservational agriculture (climate-smart agriculture) and traditional food storage systems, are essential to build our resilience to climate change.

Also, there is a need to recognise the contribution of indigenous knowledge and practises in the maintenance of biological diversity. Integrated agricultural systems based on indigenous knowledge and traditional practises provide many examples of sustainable and adaptive systems with the potential to ensure the survival of our biota and mitigate major climatic changes. The integration of both traditional wisdom and new technologies to adapt to climate change impacts offers a path to new partnerships and innovative ways of thinking.

Climate change effects are felt significantly by rural smallholder farmers as they experience reduction in yields, crop failure, loss of assets, and livelihood opportunities (Cherotich et al., 2012). Despite such challenges, farming has continued in rural areas over the years. According to Nkomwa et al. (2014), rural smallholder farmers have been relying on their indigenous knowledge (IK) to sustain themselves and maintain their cultural identity. Indigenous knowledge systems are based on skills and practises used by local communities to predict events or situations (Jiri et al., 2015). Though indigenous knowledge offer some relief to especially short term weather variability, its usefulness is limited with regards to long term climate change effects and thus requires harnessing with modern technologies. In this regard, the usefulness of indigenous knowledge and technologies in dealing with short term weather events and how to make these technologies relevant for climate change mitigation and adaptation are discussed in this chapter.

\section{METHODOLOGY}

This chapter was written with information from available literature on indigenous knowledge, practises, and technologies and climate change. The literature search was conducted according to the procedure used by Petzold et al. (2020). The main data bases searched were Google Scholar, Web of Science and Scopus. However, some literature materials found in these data bases were under restricted-access (available at a fee). Thus to avoid information coverage limitation presented by this challenge, searches were extended to other sources including google and websites of reputable institutions and journals. The search was on all available published materials using the keywords; Indigenous, climate-change, mitigation, adaptation, sustainable-agriculture. No restriction was placed on year of publication. The search was further finetuned by the following questions.

- Which indigenous knowledge and technologies are used for weather prediction?

- Which indigenous knowledge and technology can be used for climate change mitigation?

- Which indigenous knowledge and technology can be used for climate change adaptation?

- Which indigenous conservational agriculture practises represents efficient use of land and water resources?

\section{CLIMATE CHANGE}

Climate change is the gradual change in the long-standing state of the atmosphere over several decades (Uejio et al., 2015). Globally, climate change is a concern due to its effects on sustainable development. It threatens biodiversity and ecosystems, and affects human settlements, water resources, and the frequency of extreme weather events, with substantial consequences on economic output, food production, human wellbeing, and socioeconomic activities. Climate change is caused by the presence of high levels of of greenhouse gases (GHG) in the atmosphere.

Unfortunately, human activities have contributed great quantities of greenhouse gases $\left(\mathrm{CO}_{2}, \mathrm{~N}_{2} \mathrm{O}, \mathrm{CH}_{4}\right)$ since the industrial revolution. These GHGs act like a blanket and trap heat from the sun instead of releasing it back into space (Public Health Institute/Center for Climate Change, 2016).

Since 1990, the global GHGs emissions have increased by 1.5-fold driven by increasing fossil energy use and economic growth in developing countries. $\mathrm{CO}_{2}, \mathrm{~N}_{2} \mathrm{O}$, and $\mathrm{CH}_{4}$ account for about $98 \%$ of the total emissions of GHGs (IEA, 2020). $\mathrm{CO}_{2}$ has the greatest GHG effect. In 2013, 82\% $\mathrm{CO}_{2} \mathrm{GHG}$ emissions was attributed to human activities in the United State (United States Environmental Protection Agency, 2016). Incomplete combustion of fossil fuels (coal, oil, and gas), transportation and electricity production releases the most of $\mathrm{CO}_{2}$.

Climate change is a major challenge for agriculture (Thornton et al., 2011), water availability, food security, and rural livelihoods (Naresh et al., 2017). Also, climate change will greatly impact the quality and quantity of groundwater resources that supports 1.5-3 billion people worldwide (Kundzewicz and Doll, 2009). Its negative effects on sea levels, river flows and rainfall pattern is also anticipated (IPCC, 2008). For example in Sub-Saharan Africa, by the year 2050 rainfall might drop by $10 \%$ and this will result in major water shortages (Nyong, 2005). There are 
also risks of pest infestation and flooding across the world (Beddington et al., 2012).

\section{THE USE OF INDIGENOUS TECHNOLOGIES TO PREDICT WEATHER CHANGES}

Small farm holders in Africa have historically utilised several indigenous signs for weather prediction based on environmental and cultural beliefs (Ubisi et al., 2019). The most common indicators used by rural farmers are animal indicators, plant indicators, atmospheric indicators, and human ailments. These signs are used to make farm-level decisions regarding farming systems such as time of planting and the choice of crops to cultivate (Acharya, 2011; Mosime, 2018; Ubisi et al., 2019). However, the signs used can be misleading. Thus, their use especially in today's world is rather limited and require augmentation with modern technology (see Improving the Effectiveness of Indigenous Technologies Through Science section)

For instance, the appearance of a local bird known as a sparrow is an indication of rain coming in a day and the croaking of frogs indicates the highest likelihood of rain (Breuner et al., 2013; Elia et al., 2014; Ubisi et al., 2019). Though these may align with science, the scientific interpretations differ. In biology for example, the croaking of frogs is associated with mating and not rain bearing clouds though mating usually happens in the rainy season.

Many rural smallholder farmers hold the belief that excessively hot temperatures between September and December signify heavy rains (Risiro et al., 2012). With the assurance of rains from these signs, farmers choose to cultivate water-loving food crops like rice to maximise the benefits of the available water resources. These predictions also affect land management as farmers may shift their attention to wetlands leaving other areas to fallow. Livestocks may also be bred within selected areas because of the availability of fodder there and thus, control grazing is practised.

Also, indigenous farmers interpret the appearance of termites without wings together with colourful locusts as an indication of a prolonged dry spell (Chikaire et al., 2018; Ubisi et al., 2019). How this works well requires scientific investigation and results from this can be used to develop artificial intelligence biosensors/markers which provides more reliable information. This way, the indigenous knowledge is harnessed not replaced. Moreover, a hazy morning means very high temperatures should be expected during the day (Risiro et al., 2012) and a low summer rainfall indicates a warmer winter (Mapara, 2009). In preparation for the drought season, farmers may choose to use high ridges together with mulch to improve water retention in soils, planting crops (maize and sorghum) with low water requirements and agroforestry practises may also be adopted. The harvesting of rainwater for the watering of animals and crops may also be practised (Basdew et al., 2017), the shifting of planting seasons to suit the availability of rains may be the best adaptation strategy (Nkomwa et al., 2014; Soropa et al., 2015) according to water system plans (Mukhopadhyay, 2009).
Indigenous people have long known the importance of agroforestry for the management of water and land resources and for food security. The use of agroforestry by indigenous people after the prediction of an impending low rain season is because of its nutrient replenishing advantage (Rosenstock et al., 2019). The woody species within agroforestry systems (AFS) can considerably impact the water availability for agricultural crops (Rosenstock et al., 2019). This is because the roots of trees penetrate deeper into the soil than many crops and hence capable of increasing the water infiltration rate and capacity (Anderson et al., 2009). Trees and shrubs can also increase evapotranspiration by absorbing water from deeper soil layers and redistributing it towards the surface (Domec et al., 2010). This benefit crops in agroforestry systems. However, this can lead to competition, particularly in dry areas where water is a limiting factor for plant growth (Zhang et al., 2018). The wider benefit of water redistribution includes not only the upward movement of water during dry spells but also the movement and storage of excess water in the sub-surface from deeper soil layers. This makes the root system a mechanism for the balancing of soil water gradients (Burgess, 2011). Nitrogen-fixing trees and shrubs have important ecological potential in dryland forestry and are often integrated into AFS such as silvopastoral systems (Sierra et al., 2002). This contributes to sustainable agriculture by restoring and maintaining soil fertility and productivity (Bronick and Lal, 2005). The role of "fertiliser trees" and their contributions towards food production and security has been well-elaborated by Sileshi et al. (2014).

\section{INDIGENOUS KNOWLEDGE AND TECHNOLOGIES WITH POTENTIALS FOR CLIMATE CHANGE MITIGATION}

The indigenous people around the world have used several prohibitions or taboos to indirectly conserve the environment. For example, in the past, the Cherokee resisted the Tellico Dam project and also, the flooding of the Little Tennessee Valley (Whitt, 1999). Though their opposition to the project was based on the protection of their culture, it had environmental benefits such as the prevention of the release of carbon from the cutting and burning of wood, and the disturbances of stable soils. Besides the preservation of the rich biodiversity of the valley, the maintenance of carbon sinks, there is the additional benefit of the stable ecosystem (Little Tennessee Valley) holding on to its resilience against the occurrence of higher numbers of pest and diseases which are associated with climate change.

Also, the Ojibwe people (Northern America descendants) promoted the conservation of biodiversity and land by emphasising that "we take only what we need" (Chapeskie, 1999). Such believes promote the sustainable use of land, water, and food resources and prevent the excesses which lead to climate change. This also promotes the spirit of equity and togetherness and also benefits animals and plants because of the belief that nature is part of humanity and should be treated as such. With this mindset, the Ojibwe people believed that nature reciprocates 
what humans do to it and thus the environment is protected to prevent "curses" from nature (Climate change).

Sacred groves have also been used by some indigenous people to conserve nature and indirectly mitigate effects which could culminate into climate change. One negative effect of climate change is the loss of natural gene pools. However, mountains that are held as sacred groves/protected areas protect and hold gene pools that can be relied on when such genes are endangered outside the wild. Keeping mountains as sacred groves/protected areas enhances the development of thick forests which serve as carbon sinks and thus can mitigate the effects of climate change. Water resources within these sacred groves are also protected. The Holy Hills of south-western China are held as gardens of the gods and thus are untouched by farming and hunting (Bernbaum, 1999). The institution of such establishments can help mitigate climate change.

Moreover, sacred groves can serve as an equally effective option to modern protective measures used to protect designated areas (e.g., game reserves, forests) across the world (Bernbaum, 1999). Several forests across the developing world exist because of the reverence or sacredness given to them. In a broader sense, sacred groves serve as natural food and water buffers that can be relied on for the mitigation of the effects of climate change (e.g., water and food shortages). Sacred forests also have rich soils which when used in agroforestry systems can mitigate the problem of poor soils that are exacerbated by climate change. The establishment of sacred sites can be an effective environmental management technique for the restoration of degraded areas in the under developed world.

Indigenous people in the past have stored foodstuff and seeds in small but effective storage facilities on farms and in their homes to conserve viable seeds and for food security. These methods were devoid of today's chemical food additives. These methods could keep food and seeds between seasons and in some cases for several years. Among the most notable storage methods used included sun drying, use of salt, ash, garlic, lime powder, and dried red chilies (Prakash et al., 2016). These methods can be equally effective in mitigating the effects of climate change on humans if harnessed with modern technology. Grain detectors which work on the principles of artificial intelligence can be used to harness these indigenous practise. On the other hand, artificial intelligence programming can have algorithms which incorporates the discussed indigenous technologies as a way of making them (new technologies) acceptable to rural folks who wouldn't want to abandon their cultural practises.

\section{INDIGENOUS KNOWLEDGE AND TECHNOLOGIES WITH POTENTIALS FOR CLIMATE CHANGE ADAPTATION}

Three key highlights of indigenous knowledge and practises that are significant in native resources management include a social organisation that controls resources in the community, native methods for saving and preserving resources, and the customary norms and techniques for control, procurement, support, and transfer of natural resources (Luoga et al., 2000). Also, indigenous agroforestry hones such as the addition of leguminous trees into fallow periods between two cropping seasons (progressed fallow), or intercropping brief and long-term trees with crops (scattered intercropping), can lead to higher crop yields in numerous parts of the tropics (Hall et al., 2005).

Rural agriculturists in most of the African nations have been planting trees and when harnessed with modern tree planting technologies (DroneSeed automation tree planting) can be effective adaptation measures to climate change impact on land, water, and food resources. Agroforestry can be a level-headed land-use arrangement that explores balance/s between the raising of forests and food crops (Adesina et al., 1999). For instance, in Southern Africa, land-use conversion like the shift to game farming instead of livestock farming is encouraged (Ziervogel et al., 2008). In addition, agroforestry procedures can be used to change environmental conditions (drier conditions) through soil conditioning (organic matter content and mulch). This improve agricultural efficiency and lessens the over-exploitation of land by making possible the use of limited land space for several agricultural purposes (farming, animal rearing, aquaculture).

Accentuating on more crops that are drought resistant in drier areas may aid in minimising our susceptibility to climate change. Hence, different crops have been used by smallholder farmers as adaptation strategies to climate change in Burkina Faso, Senegal, Nigeria, and Ghana (Ngigi, 2009). Also, crop diversity may be a tall need in both flooded and non-irrigated ranges. In Darfur and Kordofan states of Western Sudan, cash crops have been replaced with food crops and crop varieties that are resilient to unfavourable climates (Akinnagbe and Irohibe, 2014). Farmers in Tanzania diversify crop types to reduce risks (Adger et al., 2003). Diversification of crops should be harnessed as a function for insurance against rainfall variability and or water scarcity. Local water-use practises (sharing water resources between man, animals, and crops) are adaptive to climate, and these should be considered whilst presenting alternatives. Soil protection strategies are progressively rehearsed in most African countries in line with adaptation to climate change.

Indigenous practises such as conservation tillage minimises the dangers from drought by minimising soil erosion, enhancing moisture retention, and minimising soil impaction. In combination, these benefits ensure resilience to climatic impacts of flood and drought. Traditional farmers have created different and privately adjusted agrarian frameworks for quite a long time, and have overseen them with native practises that were regularly successful in guaranteeing food security (Altieri, 2004). For instance, native individuals used the enormous appearance of Christmas beetles (Anoplognathus spp.), to predict typically or above ordinary precipitation seasons, with a chance of flooding in low-lying zones (Chanza and Mafongoya, 2018). Accepting and harnessing, native climate-smart strategies can supplement logical conventional climate services that are more reliable (Mafongoya et al., 2017).

In managing soil fertility, farmers have been using customary strategies to improve soil quality, for e.g., land fallowing (Vanlauwe et al., 2010). Also, in Lesotho, native farmers have utilised conventional cultivating systems (Machobane cultivating framework) to improve soil fertility under environmental change 
(Mafongoya and Ajayi, 2017). Further, sustainability, scaling, and adoption of water-smart strategies such as harvesting of rainwater have likewise profited native knowledge systems (Reij et al., 2013). The accomplishment of such systems has been for the most part a direct result of the effectiveness of watergathering systems with local styles, local organisations, and local social frameworks. Selection and scaling of inventive practises in natural resources management have likewise profited native information (Luoga et al., 2000).

Indigenous people have rich traditional practises and knowledge when harnessed can play an instrumental role in sustainable development and effective climate change adaptation. The practises and knowledge of the aboriginal peoples are playing significant roles in forestry and sustainable agriculture, providing ecosystem services, and protecting ecosystems for carbon storage (Oral Statement of the Special Rapporteur, 2016). This knowledge and practises of the indigenous people serve as basics for reducing emissions resulting from land degradation and deforestation. The indigenous practise of maintaining streams, rivers, dams, dugouts through taboos, and the capturing of water in drylands for livestock is now considered as adaptation strategies to combat climate change. Indigenous people also support these with hunting, gathering of wild food, and fishing (Gyampoh et al., 2019).

\section{INDIGENOUS CONSERVATIONAL AGRICULTURE PRACTISES FOR EFFICIENT USE OF LAND AND WATER RESOURCES}

\section{Intercropping}

The growing of many crop species on a land unit simultaneously using ecological concepts including competition, facilitation, and diversity is termed intercropping (Hauggaard-Nielsen et al., 2008). This practise is very productive (Hu et al., 2017). Since certain crops have varying climate adaptability, intercropping eliminates overall crop loss (Hosen et al., 2020). Singh and Singh (2017) pointed out that intercrops improve land, water, and nutrient, light, biodiversity, productivity, resiliency, and the efficient use of agro-ecosystem stability. Intercropping is a traditional agricultural practise that primarily involves intercropping legumes and crops (Daryanto et al., 2020). Hu et al. (2017) stated that wheat and maize coupled with agricultural conservational techniques decrease carbon dioxide release and upsurge crops' output. Intercropping is a cost-effective and environmentally sustainable approach for carbon sequestration while still delivering economic benefits (Wang et al., 2019). When legumes and cereals are intercropped, they enhance the easing of nutrients that are limiting (Layek et al., 2018).

Legumes have a mutually beneficial relationship with rhizobium bacteria which help fix nitrogen (Duchene et al., 2017). Applying legumes to farmlands lessens the $\mathrm{N}_{2} \mathrm{O}$ emission of farmlands while augmenting nitrogen-holding compounds that are mineralizable in the soil (Scalise et al., 2017). $\mathrm{N}_{2} \mathrm{O}$ is likely to increase global warming by 298 -folds than $\mathrm{CO}_{2}$, and agriculture accounts for roughly $60 \%$ of overall anthropogenic
$\mathrm{N}_{2} \mathrm{O}$ emissions (Singh and Singh, 2017). Increasing nitrogen fertilisers application alters the climate system and $\mathrm{N}$ cycle by emitting $\mathrm{N}_{2} \mathrm{O}$ (De Rosa et al., 2018). Intercropping with legumes removes the application of nitrogen fertilisers and other external inputs. They increase nitrogen and phosphorus supply for crop development and nutrient quality (Latati et al., 2017). Intercropping maize with legumes lessens the leaching of nitrate and the input of inorganic fertilisers and improves soil health, crop yield, and agro-biodiversity (Reddy, 2016). Intercropping of legumes in green manure decreases soil's erodibility, thus enhancing stability in soil aggregates and encouraging $\mathrm{N}$ retention in soil (De Oliveira et al., 2020).

Many reports prove that agroforestry system nutrient loss is less as compared to agriculture farming. The report by Grewal et al. (1994) shows that leucaena-napier grass had low nutrient loss than the traditional agricultural system. There was a net gain of $38 \mathrm{~kg} \mathrm{~N}, 10 \mathrm{~kg} \mathrm{P}$, and $20 \mathrm{~kg} \mathrm{~K}$ as compared to the net loss of $15 \mathrm{~kg} \mathrm{~N}, 2 \mathrm{~kg} \mathrm{P}$, and $14 \mathrm{~kg} \mathrm{~K} / \mathrm{ha}$ in the traditional agricultural system.

In general terms, intercropping offers numerous ecosystem services including weed control, impeding disease cycles and pest outbreaks, sequestering carbon to boost soil organic matter, supporting pollinator and natural enemy populations, and helping mobilise other limiting nutrients such as phosphorus (Wick et al., 2017).

\section{Cover Cropping}

Cover cropping is a long-standing ecological technique for improving soil microbial biomass, soil health, and agroecosystem resources, including retention water, cycling of nutrients, carbon sequestration, weed, and pest control (Pinto et al., 2017). Cover crops are crops cultivated to shelter the ground, thus decreasing nutrient loss and soil erosion (Dabney et al., 2001). The cultivation of cover crops is between major crops to increase agricultural productivity. These are leguminous crops cultivated to cover the soil surface and aid in improving soil physical, chemical, and biological properties (Sharma et al., 2018).

Qi and Helmers (2010) observed that using cereal rye as a cover crop in a maize-soybean system improved soil water retention. Cover crops assist to minimise soil evaporation, store moisture from the irrigation and rainfall, and increase soil moisture availability to succeeding crops. Basche et al. (2016) also found that cover crops improved water retention in the soil by $10-11 \%$ and $21-22 \%$ at water potentials related to field capacity and plant accessible water, respectively. Cover crops lower the intensity of rainfall. As a result, increased water infiltration instead of drainage results and this boosts soil water storage (Sammis et al., 2012).

From 2006 to 2012, the Lithuanian Research Centre for Agriculture and Forestry ran a field study to examine the competitive ability of narrow-leafed lupine coupled with oil radish, white mustard, and white mustard combined with buckwheat cultivated as cover crops. The researchers found that white mustard cultivated alone or coupled with buckwheat was more effective for weed smothering than the narrow-leaf lupine coupled with oil radish in an organic farming system. In 
comparison to plots cultivated with cover crops, crops cultivated without cover crops in both low and high humus content soils had a higher quantity and biomass of weeds. The findings showed that white mustard and white mustard coupled with buckwheat were efficient in constraining volunteer plants and weed biomass in soils with low and high humus content.

The study concluded that cover crops have a ability to suppress weed development, and may be employed as a device to control weed in crops (Masilionyte et al., 2017).

Cover crops' potential to increase soil organic carbon (SOC) has been discussed in limited studies (Lal, 2004). Agricultural soils are depleted in SOC as compared to soils under natural vegetation cover. Crop cultivation leads to SOC losses of 30$40 \%$ in comparison to natural vegetation (Don et al., 2011). SOC sequestrated in conventional tillage and no-till soils can be influenced by different crop management practises due to the difference in plant carbon inputs and rate of mineralization. The SOC at $0-30 \mathrm{~cm}$ depth was increased to $120-130 \mathrm{~kg}$ Nha/year in cover crops treatment in comparison to $0 \mathrm{~kg} \mathrm{~N} / \mathrm{ha} /$ year in no cover crop treatment (Sainju et al., 2006). Cover crops can decrease nutrient requirement particularly nitrogen for the subsequent crop. Nitrogen is captured by roots, and this prohibits the nitrate leaching into groundwater, and prohibit downward movement into the soil profile (Elia et al., 2014). An experiment was conducted from 1992 to 1994 in Sweden to estimate the effect of perennial ryegrass (Lolium perenne L.) as a cover crop sown in barley to determine nitrate leaching and availability of nitrogen to the main crop. Results showed that cover crop reduced the concentration of nitrate leaching by $<5 \mathrm{mg} / \mathrm{L}$ as compared to 10-18 mg/L without cover crop (Bergstrom and Jokela, 2001). Oats (Avena sativa L.) and rye (Secale cereale L.) cover crops were evaluated with regards to reducing nitrate concentrations. Oats reduced nitrate concentration by $26 \%$ whereas rye reduced $48 \%$ nitrate concentration (Kaspar et al., 2012).

Cover crops are able to mitigate warming through greenhouse gas flux by $100-150 \mathrm{~g} \mathrm{CO}_{2} \mathrm{e} / \mathrm{m}^{2} /$ year which is higher as compare to mitigation through no-till. An estimation using case studies to calculate the change of surface albedo due to cover crops showed mitigation around $12-46 \mathrm{~g} \mathrm{CO}_{2} \mathrm{e} / \mathrm{m}^{2} /$ year over 100 years. Cover crops management help climate change mitigation through reduction of erosion from rains, retention in mineralized nitrogen due to warming, and increases soil water management options during soil saturation period or in droughts (Kaye and Quemada, 2017).

In Ghana, they are practised traditionally, and indigenous people grow pigeon pea, cowpea, mucuna, dolicos, and stylosanthes which shield the soil from erosion and weeds. Cover crops are long-term agricultural tools that recover soil-water dynamics and upsurge soil organic matter in soils (Ross, 2017). In a cropping system of maize and soybean, water content is improved in the soil (Basche et al., 2016). They improve nitrogen or recover nitrogen by fixation or mineralization, thus lessening inorganic fertilisers' input and subsequent greenhouse gases (GHGs) emissions to the agro-ecosystem (Ben-Salem et al., 2018). Cover crops that are leguminous supply nitrogen adequately to crops cultivated in rotation and decline external inputs of inorganic fertilisers (Robacer et al., 2016). Grasses and legumes are sustainable tools to support soil resources, water conservation, and nutrient cycling (Jahanzad et al., 2017). Leguminous cover crops boost soil organic matter, biodiversity, and carbon sequestration (Lal, 2011). Soil organic carbon augmentation, which involves carbon sequestration, is crucial for upsurging soil ecosystem services (Hwang et al., 2017).

\section{Crop Rotation}

Crop rotation is a historic technique used for centuries and involves farming various plants on land (Hobbs et al., 2008; Dury et al., 2012). Crop rotation is important in sustainable systems because it boosts beneficial species and interactions, breaks the cycle of pathogens, and lessens weed populations. Legumes in crop rotation provide the system with symbiotically fixed nitrogen, help in maintaining water status, and lower pathogen burden. Crop rotation has been demonstrated to have a beneficial effect on crop growth in many studies which have been attributed to changes in the bacterial community composition (Wortman et al., 2013). When compared to grains in multiple crop rotations, continuous monocropping caused changes in the soil ecosystem, increasing pathogen load and decreased the development of barley (Kennedy, 1999).

Globally, it is gaining attention to answer the upsurging agro-ecological difficulties, including decreased soil quality and climate changes due to farm methods short of rotation (Liu et al., 2016). It is a practical technique for sequestering carbon when compared to the constant farming of the same crops (Triberti et al., 2016). It potentially reduces $\mathrm{CH}_{4}$ and other GHGs emissions in rice irrigated fields (Theisen et al., 2017). The rice cultivation in rotation with corn and sweet sorghum during the dry season, Cha-un et al. (2017) found a substantial decrease in GHGs emission by $68-78 \%$ relative to double rice cultivation. It is also a long-term method for increasing crop yields and efficient use of water while decreasing soils' erodability (Huang et al., 2003).

The rotation of crops improves soil health and the productivity of crops by changing the structure and the aggregation of soil, soil organic carbon, cycling of nutrients, and pest and disease control (Jarecki and Lal, 2003). Choosing a crop for rotation is critical, and species that improve nitrogen rises the next crop's phytomass production and increases organic matter in the soil (Singh and Singh, 2017). Increasing soil organic matter is an environmentally friendly way to boost crop productivity while maintaining the carbon cycle and improving carbon sequestration. Lehmann and Kleber (2015) found that higher amounts of organic carbon are deposited in soil than in the atmosphere and vegetation. Leguminous crops lessen the dependence on nitrogen fertilisers that releases $\mathrm{N}_{2} \mathrm{O}$ and reducing the emission of $\mathrm{CO}_{2}$ (Wang et al., 2019).

Additionally, such crops sequester carbon in soils (Lal, 2011). It is anticipated that the rotation of corn-soybean enhances the of crops productivity and residues relative to the monoculture of corn or soybean (Wang et al., 2019). Cowpea is a droughttolerant indigenous crop cultivated in the semi-arid tropics of Africa, Asia, and the Americas. They are vital leguminous crops, food for both man and livestock, and efficient nitrogen fixers in sandy and nutrient-poor soils (Singh et al., 2003). 


\section{Agroforestry}

Trees fix carbon during the process of photosynthesis and reserve surplus carbon as biomass (Nowak and Crane, 2002). Agroforestry is establishing trees in combination with crops and animals to economically and ecologically achieve positive interactions between different components (Nair et al., 2010). They are climate-smart practises that are generally adopted owing to their ability to improve food security, mitigate climate change, and improve crop productivity (Coulibaly et al., 2017). The agroforestry practise boosts soil organic matter, sequester carbon, retain water, farmers' income, agrobiodiversity, and agriculture productivity (Paul et al., 2017). Agroforestry systems function as atmospheric carbon sinks. When compared to agricultural plants or pasturelands, agroforestry systems trap more carbon in the atmosphere (Tomar et al., 2021). The capability of Agroforestry systems to sequester carbon is affected by various factors including age and tree species, geographical location, environmental factors, management practises, and agro-ecosystems type (Jose, 2009). Trees in croplands reduce extreme weather events, including floods, tropical storms, and hurricanes (Matocha et al., 2012) or are used as windbreaks and shelterbelts (Lasco et al., 2014).

Agroforestry practise is recognised globally as a land-use management system but common in the tropics (Pandey, 2002). It is found in Equatorial Africa, Latin America, and Southeast Asia (Szott et al., 1991). In developing countries, rural folks rely on this practise to sustain agricultural productivity and livelihoods (Meijer et al., 2015). In West and Central Africa, cocoa agroforestry is an old technique of combining forest components with crops. The multi-strata agroforestry offers agroforestry tree products, including fruits and timber (Simons and Leakey, 2004). The combination of animals into the system presents both meat and milk to the farmer, and their feces are recycled as not into manure to sequester carbon (Altieri, 1999). Agroforestry offers and not encourages several ecosystem services like improvement in soil quality, water conservation by slowing down surface runoff, reducing sediment transportation, soil biodiversity, enhances carbon sequestration, and increases various food and cover for wildlife habitat (Udawatta et al., 2017). Though these services are intertwined and difficult to quantify on their own, agroforestry potentially can promote economic, environmental, social vitality, and land sustainability (Udawatta et al., 2017). Sileshi et al. (2007) reported that when agroforestry is deliberately and appropriately planned, agroforestry practises can improve ecosystem services by modifying degraded land, climate change, and desertification while increasing the structural and functional diversity of the agricultural landscapes.

Agroforestry practises are good for drought conditions, as trees' deep roots make nutrients in the soil available for plant use (Rao et al., 2007). Agroforestry is accepted as an environmentally friendly technique for food production in the existing situation of food shortages and climate change (Mbow et al., 2014). In the drought-prone areas of the Sahel, agroforestry has grown to include the baobab (Adansonia digitata) and acacia (Acacia) trees and they are regarded as good candidate trees for agroforestry in these areas (Nyong et al., 2007).

\section{IMPROVING THE EFFECTIVENESS OF INDIGENOUS TECHNOLOGIES THROUGH SCIENCE}

The prediction of weather events and seasons with indigenous knowledge is fascinating especially when such predictions come to pass. However, there are high degrees of uncertainty associated with these predictions especially in today's world where anthropogenic activities have altered many environmental processes. The flying of sparrows today may signify a pollution event and not the ushering in of rains. Because of these changes in events, there is a need to improve our indigenous practises/technologies. However, in improving indigenous technologies care should be taken not to erase such knowledge and practices because of the need to preserve cultural heritages. Thus, new technologies incorporating the internet of things can be designed to have components of indigenous technologies in them. Smarter monitoring tools which combine the flying of sparrows and movement of locusts with changes in moisture/wind direction for weather monitoring can be produced. Such technologies will be easily accepted by indigenous people because of the inclusion of cultural beliefs and the relative ease of interpretation. These technologies can be developed based on artificial intelligence. With technologies like these in place, weather events can be better predicted and appropriate climate change mitigation and adaptation strategies readied for implementation.

Sacred groves unlike modern proctected areas gain their effectiveness from myths. Whilst science has effectively unravelled the myths behind this practise, sacred groves are still protected in many countries of the world. In some areas however people illegally exploit the resources preserved in these sacred places. To combat such illegal activities and for that matter preserve the rich land, water, and food resources in the groves, some advanced monitoring devices are required. Devices that are capable of offering aerial and terrestrial-monitoring. Monitoring in terms of trees fell, animals hunted, water pollution, and the degradation of soils. Robotics (drones) and the applications of tracer studies can present unique advantages in this direction.

Irrigation is not new to the indigenous farmer however to manage water use in this era of water scarcity, advanced technologies such as drip irrigation technology is necessary. This ensures enough water supply to crops and minimises water evaporation losses. Water abstraction from water sources can also be controlled using automated monitoring devices that ration water between several uses (watering of plants and animals). Such devices may also guide the development and maintenance of dams vis-a-vis the availability of lands and the priorities of beneficial communities.

The old-age farm practises of intercropping, cover cropping, crop rotation, and agroforestry can all be improved upon to make them more beneficial in the face of climate change. Effective plant-plant distances, plant water requirements, the timing of planting and harvesting can all be automated to improve yields. With modern scientific knowledge, disease-prone seeds, seedlings, and plants can easily be identified and eliminated to reduce losses. Food and seed storage methods such as sun 
drying can be improved upon with automated sun dryers, whiles the use of methods like the application of ash and garlic can be improved through the automated screening and selection of quality (devoid of contaminants) ash and garlic.

Information systems can also be developed to enable the sharing of information between farmers, and other land and water users. Smartphones are a practical option that can accommodate various means of communication including sign language, voice messages, graphs, videos, and alarm systems. These phones can also be designed to monitor local weather conditions and automatically trigger messages to decisionmakers including farmers.

\section{CONCLUSION}

Indigenous knowledge and technologies can be useful for combating the effects of climate change on humans and other biotas. The indigenous technologies and practises that have the potential to offer some solutions to climate change problems have been identified and discussed in this chapter. After the

\section{REFERENCES}

Acharya, S. (2011). Presage biology: lessons from nature in weather forecasting. Indian J. Tradit. Knowl. 10, 114-124. Available online at: http://nopr.niscair. res.in/handle/123456789/11072

Adesina, F. O., Siyambola, W. O., Oketola, F. O., Pelemo, D. A., Ojo, L. O., and Adegbugbe, A. O. (1999). Potentials of agroforestry for climate change mitigation in Nigeria: some preliminary estimates. Glob. Ecol. Biogeogr. 8, 163-173. doi: 10.1046/j.1365-2699.1999.00122.x

Adger, W. N., Huq, S., Brown, K., Conway, D., and Hulme, M. (2003). Adaptation to climate change in the developing world. Prog. Dev. Stud. 3, 179-195. doi: 10.1191/1464993403ps060oa

Akinnagbe, O. M., and Irohibe, I. J. (2014). Agricultural adaptation strategies to climate change impacts in Africa: a review. Bangladesh J. Agr. Res. 39, 407-418.

Altieri, M. A. (1999). "The ecological role of biodiversity in agro-ecosystems," in Invertebrate Biodiversity as Bioindicators of Sustainable Landscapes (Amsterdam: Elseiver), 19-31. doi: 10.1016/B978-0-444-50019-9.50005-4

Altieri, M. A. (2004). Linking ecologists and traditional farmers in the search for sustainable agriculture. Front. Ecol. Environ. 2, 35-42. doi: 10.1890/15409295(2004)002[0035:LEATFI]2.0.CO;2

Anderson, S. H., Udawatta, R. P., Seobi, T., and Garrett, H. E. (2009). Soil water content and infiltration in agroforestry buffer strips. Agrofor. Syst. 75, 5-16. doi: 10.1007/s10457-008-9128-3

Basche, A. D., Kaspar, T. C., Archontoulis, S. V., Jaynes, D. B., Sauer, T. J., Parkin, T. B., et al. (2016). Soil water improvements with the long-term use of a winter rye cover crop. Agric. Water Manag. 172, 40-50. doi: 10.1016/j.agwat.2016.04.006

Basdew, M., Jiri, O., and Mafongoya, P. L. (2017). Integration of indigenous and scientificknowledge in climate adaptation in KwaZulu- Natal, South Africa. Change Adapt. Soc. Ecol. Syst. 3, 56-67. doi: 10.1515/cass-2017-0006

Beddington, J. R., Asaduzzaman, M., and Clark, M. E. (2012). What next for agriculture after Durban. Science 335, 289-290. doi: 10.1126/science.1217941

Ben-Salem, N., Álvarez, S., and López-Vicente, M. (2018). Soil and water conservation in rainfed vineyards with common sainfoin and spontaneous vegetation under different ground onditions. Water 10,1058. doi: $10.3390 /$ w10081058

Bergstrom, L. F., and Jokela, W. E. (2001). Ryegrass cover crop effects on nitrate leaching in spring arley fertilized with $15 \mathrm{NH}_{4} 15 \mathrm{NO}_{3}$. J. Environ. Qual. 30, 1659-1667. doi: 10.2134/jeq2001.3051659x

Bernbaum, E. (1999). "Mountains: the heights of biodiversity," in Cultural and Spiritual Values of Biodiversity, eds D. A. Posey (Nairobi: United Nations Environment Programme), 327-332. doi: 10.3362/9781780445434.008 analysis of selected indigenous knowledge and technologies, the use of changes in weather patterns, behaviour of some fauna and long standing indigenous agricultural practises were found to be useful tools and strategies for mitigating and building the resilience of communities to climate change. This knowledge and technologies are however limited in today's modern world and thus need to be harnessed using scientific knowledge and technologies (artificial intelligence, internet of things).

\section{DATA AVAILABILITY STATEMENT}

The original contributions presented in the study are included in the article/supplementary material, further inquiries can be directed to the corresponding author.

\section{AUTHOR CONTRIBUTIONS}

All authors contributed equally to the conceptualisation, drafting, and editing of the chapter.

Breuner, C., Sprague, R. S., Patterson, S. H., and Woods, H. A. (2013). Environment, behavior and physiology: do birds use barometric pressure to predict storms? J. Exp. Biol. 216 (Pt 11), 1982-1990. doi: 10.1242/jeb.081067

Bronick, C. J., and Lal, R. (2005). Soil structure and management: a review. Geoderma, 124, 3-22. doi: 10.1016/j.geoderma.2004.03.005

Burgess, S. S. O. (2011). Can hydraulic redistribution put bread on our table? Plant Soil 341, 25-29. doi: 10.1007/s11104-010-0638-1

Chanza, N., and Mafongoya, P. L. (2018). "Indigenous-based climate science from the Zimbabwean experience: from impact identification, mitigation and adaptation," in Indigenous Knowledge Systems and Climate Change Management in Africa, eds P. L. Mafongoya and O. C. Ajayi (Wageningen : CTA), 67-94.

Chapeskie, A. J. (1999). "Culture, landscape and diversity," in Cultural and Spiritual Values of Biodiversity, eds D. A. Posey (Nairobi: United Nations Environment Programme), 76-79.

Cha-un, N., Chidthaisong, A., Yagi, K., Sudo, S., and Towprayoon, S. (2017). Greenhouse gas emissions, soil carbon sequestration and crop yields in a rainfed rice field with crop rotation management. Agric. Ecosyst. Environ. 237, 109-120. doi: 10.1016/j.agee.2016.12.025

Cherotich, V. K., Saidu, O., and Bebe, B. O. (2012). Access to climate change information and support services by the vulnerable groups in semi-arid Kenya for adaptive capacity development. Afr. Crop Sci. J. 20, 169-180. doi: 10.4314/ACSJ.V20I2

Chikaire, J. U., Ajaero, J. O., Ibe, M. N., Orusha, J. O., and Onogu, B. (2018). Relevance of indigenous knowledge in weather and climate forecast for planning farm activities by farmers in Imo State, Nigeria. Agric. Res. Technol. 19, 0036-0040. doi: 10.19080/ARTOAJ.2018.19.556082

Coulibaly, J. Y., Chiputwa, B., Nakelse, T., and Kundhlande, G. (2017). Adoption of agroforestry and the impact on household food security among farmers in Malawi. Agric. Syst. 155, 52-69. doi: 10.1016/j.agsy.2017.03.017

Dabney, S. M., Delgado, J. A., and Reeves, D. W. (2001). Using winter cover crops to improve soil and water quality. Commun. Soil Sci. Plant Anal. 32, 1221-1250. doi: 10.1081/CSS-100104110

Daryanto, S., Fu, B., Zhao, W., Wang, S., Jacinthe, P. A., and Wang, L. (2020). Ecosystem service provision of grain legume and cereal intercropping in Africa. Agric. Syst. 178:102761. doi: 10.1016/j.agsy.2019.102761

De Oliveira, S. M., Ciampitti, I. A., de Almeida, R. E. M., Junior, C. P., Trivelin, P. C. O., and Favarin, J. L. (2020). Closing the nitrogen budget of intercropped maize and palisadegrass. Eur. J. Agron. 119:126093. doi: 10.1016/j.eja.2020.126093

De Rosa, D., Rowlings, D. W., Biala, J., Scheer, C., Basso, B., and Grace, P. R. (2018) $\mathrm{N}_{2} \mathrm{O}$ and $\mathrm{CO}_{2}$ emissions following repeated application of organic and mineral 
$\mathrm{N}$ fertiliser from a vegetable crop rotation. Sci. Total Environ. 637, 813-824. doi: 10.1016/j.scitotenv.2018.05.046

Domec, J. C., King, J. S., Noormets, A., Treasure, E., Gavazzi, M. J., Sun, G., et al. (2010). Hydraulic redistribution of soil water by roots affects wholestand evapotranspiration and net ecosystem carbon exchange. New Phytol. 187, 171-183. doi: 10.1111/j.1469-8137.2010.03245.x

Don, A., Schumacher, J., and Freibauer, A. (2011). Impact of tropical land-use change on soil organic carbon stocks-a meta-analysis. Glob. Chang. Biol. 17, 1658-1670. doi: 10.1111/j.1365-2486.2010.02336.x

Duchene, O., Vian, J. F., and Celette, F. (2017). Intercropping with legume for agroecological cropping systems: complementarity and facilitation processes and the importance of soil microorganisms. a review. Agric. Ecosyst. Environ. 240, 148-161. doi: 10.1016/j.agee.2017.02.019

Dury, J., Schaller, N., Garcia, F., Reynaud, A., and Bergez, J. E. (2012). Models to support croppingplan and crop rotation decisions. A review. Agron. Sustain. Dev. 32, 567-580. doi: 10.1007/s13593-011-0037-x

Elia, E. F., Mutula, S., and Stilwell, C. (2014). Indigenous Knowledge use in seasonal weather forecasting in Tanzania: the case of semi-arid central Tanzania. South Afr. J. Libr. Inf. Sci. 80, 18-27. doi: 10.7553/80-1-1395

Grewal, S. S., Juneja, M. L., Singh, K., and Singh, S. (1994). A comparison of two agroforestry systems for soil, water and nutrient conservation on degraded land. Soil Technol. 7, 145-153. doi: 10.1016/0933-3630(94)90016-7

Gyampoh, B. A., Amisah, S., Idinoba, M., and Nkem, J. (2019). Using traditional knowledge to cope with climate change in Ghana. Unasylva 60, 70-74.

Hall, N. M., Kaya, B., Dick, J., Skiba, U., Niang, A., and Tabo, R. (2005). Effect of improved fallow on crop productivity, soil fertility and climateforcing gas emissions in semi-arid conditions. Biol. Fertil. Soils 42, 224-230. doi: 10.1007/s00374-005-0019-8

Hauggaard-Nielsen, H., Jørnsgaard, B., Kinane, J., and Jensen, E. S. (2008). Grain legume-cereal ntercropping: the practical application of diversity, competition and facilitation in arable and organic cropping systems. Renew. Agric. Food Syst. 23, 3-12. doi: 10.1017/S1742170507002025

Hobbs, P. R., Sayre, K., and Gupta, R. (2008). The role of conservation agriculture in sustainable agriculture. Philos. Trans. R. Soc. B: Biol. Sci. 363, 543-555. doi: $10.1098 /$ rstb.2007.2169

Hosen, N., Nakamura, H., and Hamzah, A. (2020). Adaptation to climate change: Does traditional ecological knowledge hold the key? Sustainability, 12:676. doi: 10.3390/su12020676

Hu, F., Feng, F., Zhao, C., Chai, Q., Yu, A., Yin, W., and Gan, Y. (2017). Integration of wheat maize intercropping with conservation practices reduces CO2 emissions and enhances water use in dry areas. Soil Till. Res. 169, 44-53. doi: $10.1016 /$ j.still.2017.01.005

Huang, M., Shao, M., Zhang, L., and Li, Y. (2003). Water use efficiency and sustainability of different long-term crop rotation systems in the Loess Plateau of China. Soil Till. Res. 72, 95-104. doi: 10.1016/S0167-1987(03)0 0065-5

Hwang, H. Y., Kim, G. W., Kim, S. Y., Haque, M. M., Khan, M. I., and Kim, P. J. (2017). Effect of cover cropping on the net global warming potential of rice paddy soil. Geoderma 292, 49-58. doi: 10.1016/j.geoderma.2017.01.001

IEA (2020). "Emissions of $\mathrm{CO}_{2}, \mathrm{CH}_{4}, \mathrm{~N}_{2} \mathrm{O}$, HFCs, PFCs and SF6 (Edition 2019)", in IEA $\mathrm{CO}_{2}$ Emissions From Fuel Combustion Statistics (Database). doi: 10.1787/ac0aa54c-en (accessed July 26, 2021).

IPCC (2008). Climate Change and Water, Intergovernmental Panel on Climate Change Technical Report IV. Geneva: IPCC

Jahanzad, E., Barker, A. V., Hashemi, M., Sadeghpour, A., Eaton, T., and Park, Y. (2017). Improving yield and mineral nutrient concentration of potato tubers through cover cropping. Field Crops Res. 212, 45-51. doi: 10.1016/j.fcr.2017.06.023

Jarecki, M. K., and Lal, R. (2003). Crop management for soil carbon sequestration. CRC. Crit. Rev. Plant Sci. 22, 471-502. doi: 10.1080/713608318

Jiri, O., Mafongoya, P. L., and Chivenge, P. (2015). Indigenous knowledge systems, seasonal "quality" and climate change adaptation in Zimbabwe. Clim. Res. 66, 103-111. doi: 10.3354/cr01334

Jose, S. (2009). Agroforestry for ecosystem services and environmental benefits: an overview. Agrofor. Syst. 76, 1-10. doi: 10.1007/978-90-481-3323-9_1

Kaspar, T., Jaynes, D., Parkin, T., Moorman, T., and Singer, J. (2012). Effectiveness of oat and rye cover crops in reducing nitrate losses in drainage water. Agric. Water Manag. 110, 25-33. doi: 10.1016/j.agwat.2012.03.010
Kaye, J. P., and Quemada, M. (2017). Using cover crops to mitigate and adapt to climate change. A review. Agron. Sustain. Dev. 37:4. doi: 10.1007/s13593-016-0410-x

Kennedy, A. C. (1999). Bacterial Diversity in Agroecosystems. Invertebrate biodiversity as bioindicators of sustainable landscapes. Amsterdam: Elseiver, 65-76. doi: 10.1016/B978-0-444-50019-9.50007-8

Kundzewicz, Z. W., and Doll, P. (2009). Will groundwater ease freshwater stress under climate change? Hydrol. Sci. J. 54, 665-675. doi: 10.1623/hysj.54.4.665

Lal, R. (2004) Soil carbon sequestration to mitigate climate change. Geoderma 123, 1-22. doi: 10.1016/j.geoderma.2004.01.032

Lal, R. (2011). Sequestering carbon in soils of agro-ecosystems. Food Policy 36, S33-S39. doi: 10.1016/j.foodpol.2010.12.001

Lasco, R. D., Delfino, R. J. P., Catacutan, D. C., Simelton, E. S., and Wilson, D. M. (2014). Climate risk adaptation by smallholder farmers: the roles of trees and agroforestry. Curr. Opin. Environ. Sustain. 6, 83-88. doi: 10.1016/j.cosust.2013.11.013

Latati, M., Aouiche, A., Tellah, S., Laribi, A., Benlahrech, S., Kaci, G., et al. (2017). Intercropping maize and common bean enhances microbial carbon and nitrogen availability in low phosphorus soil under Mediterranean conditions. Eur. J. Soil Biol. 80, 9-18. doi: 10.1016/j.ejsobi.2017.03.003

Layek, J., Das, A., Mitran, T., Nath, C., Meena, R. S., Yadav, G. S., et al. (2018). "Cereal+ legume intercropping: an option for improving productivity and sustaining soil health," in Legumes for Soil Health and Sustainable Management, (Singapore: Springer), 347-386. doi: 10.1007/978-981-13-0253-4_11

Lehmann, J., and Kleber, M. (2015). The contentious nature of soil organic matter. Nature 528, 60-68. doi: 10.1038/nature16069

Liu, X., Lehtonen, H., Purola, T., Pavlova, Y., Rötter, R., and Palosuo, T. (2016). Dynamic economic modelling of crop rotations with farm management practices under future pest pressure. Agric. Syst. 144, 65-76. doi: 10.1016/j.agsy.2015.12.003

Luoga, E. J., Witkowski, E. T. F., and Balkwill, K. (2000). Differential utilization and ethnobotany of trees in Kitulangalo Forest Reserve and surrounding communal lands of Eastern Tanzania. Econ. Bot. 54, 328-343. doi: 10.1007/BF02 864785

Mafongoya, P., and Ajayi, O. C. (2017). Indigenous Knowledge Systems and Climate Change Management in Africa. Wageningen: CTA.

Mafongoya, P., Jiri, O., Mubaya, C., and Mafongoya, O. (2017). "Using indigenous knowledge for seasonal quality prediction in managing climate risk in Sub-Saharan Africa," Indigenous Knowledge Systems and Climate Change Management in Africa. Wageningen: Centre for Agricultural and Rural Cooperation, CTA.

Mapara, J. (2009). Indigenous knowledge systems in Zimbabwe: juxtaposing postcolonial theory. Available online at: http://www.sedac.ciesin.columbia.edu (accessed May 7, 2019).

Masilionyte, L., Maiksteniene, S., Kriauciuniene, Z., Jablonskyte-Rasce, D., Zou, L., and Sarauskis, E. (2017). Effect of cover crops in smothering weeds and volunteer plants in alternative farming systems. Crop Prot. 91, 74-81. doi: $10.1016 /$ j.cropro.2016.09.016

Matocha, J., Schroth, G., Hills, T., and Hole, D. (2012). Integrating climate change adaptation and mitigation through agroforestry and ecosystem conservation. Agrofor. Fut. Glob. Land Use 9, 105-126. doi: 10.1007/978-94-007-4676-3_9

Mbow, C., Van Noordwijk, M., Luedeling, E., Neufeldt, H., Minang, P. A. and Kowero, G. (2014). Agroforestry solutions to address food security and climate change challenges in Africa. Curr. Opin. Environ. Sustain. 6, 61-67. doi: 10.1016/j.cosust.2013.10.014

Meijer, S. S., Catacutan, D., Ajayi, O. C., Sileshi, G. W., and Nieuwenhuis, M. (2015). The role of knowledge, attitudes and perceptions in the uptake of agricultural and agroforestry innovations among smallholder farmers in sub-Saharan Africa. Int. J. Agric. Sustain. 13, 40-54. doi: 10.1080/14735903.2014.912493

Mosime, B. (2018). The use of traditional weather forecasting by agro-pastoralists of different social groups in Bobirwa sub-district, Botswana (Master's Thesis). University of Cape Town, South Africa. 19-22.

Mukhopadhyay, D. (2009). "Cultural values, indigenous knowledge for climate change adaptations in developing countries," in IOP Conference Series, Earth and Environmental Science, vol 6. http:// iopscience.iop.org/1755-1315/6/57/572006 (accessed February 14, 2021). doi: $10.1088 / 1755-1307 / 6 / 57 / 572006$ 
Nair, P. R., Nair, V. D., Kumar, B. M., and Showalter, J. M. (2010). Carbon sequestration in agroforestry systems. Adv. Agron. 108, 237-307. doi: 10.1016/S0065-2113(10)08005-3

Naresh, R. K., Gupta, R. K., Minhas, P. S., Rathore, R. S., Dwivedi, A., Purushottam Kumar, V., et al. (2017). Climate change and challenges of water and food security for smallholder farmers of Uttar Pradesh and mitigation through carbon sequestration in agricultural lands: an overview. Int. J. Chem. Stud. 5, 221-236.

Ngigi, S. N. (2009). Climate change adaptation strategies: water resources management options for smallholder farming systems in Sub-Saharan Africa. Nairobi: The MDG Centre for East and Southern Africa, the Earth Institute at Columbia University, 189.

Nkomwa, E. C., Joshua, M. K., Ngongondo, C., Monjerezi, M., and Chipungu, F. (2014). Assessing indigenous knowledge systems and climate change adaptation strategies in agriculture: a case study of Chagaka Village, Chikhwawa, Southern Malawi. Phys. Chem. Earth 67, 164-172. doi: 10.1016/j.pce.2013.10.002

Nowak, D. J., and Crane, D. E. (2002). Carbon storage and sequestration by urban trees in the USA. Environ. Pollut. 116, 381-389. doi: 10.1016/S0269-7491(01)00214-7

Nyong, A. (2005). Abstract in Impacts of Climate Change in the Tropics: the African Experience. Exeter: Avoiding Dangerous Climate Change (Meteorological Office).

Nyong, A., Adesina, F., and Osman, E. B. (2007). The value of indigenous knowledge in climate change mitigation and adaptation strategies in the African Sahel. Mitig. Adapt. Strateg. Glob. Change 12, 787-797. doi: 10.1007/s11027-007-9099-0

Pandey, D. N. (2002). Carbon sequestration in agroforestry systems. Clim. Policy 2, 3673377. doi: 10.3763/cpol.2002.0240

Paul, C., Weber, M., and Knoke, T. (2017). Agroforestry versus farm mosaic systems-comparing land-use efficiency, economic returns and risks under climate change effects. Sci. Total Environ. 587, 22-35. doi: 10.1016/j.scitotenv.2017.02.037

Petzold, J., Andrews, N., Ford, J. D., Hedemann, C., and Postigo, J. C. (2020). Indigenous knowledge on climate change adaptation: a global evidence map of academic literature. Environ. Res. Lett. 15:113007. doi: 10.1088/1748-9326/abb330

Pinto, P., Long, M. E. F., and Piñeiro, G. (2017). Including cover crops during fallow periods for increasing ecosystem services: Is it possible in croplands of Southern South America? Agric. Ecosyst. Environ. 248, 48-57. doi: 10.1016/j.agee.2017.07.028

Prakash, B. G., Raghavendra, K. V., Gowthami, R., and Shashank, R. (2016). Indigenous practices for eco-friendly storage of food grains and seeds. Adv. Plants Agric. Res. 3, 101-107. doi: 10.15406/apar.2016.03. 00101

Public Health Institute/Center for Climate Change, and Health (2016). Climate Change 101: Climate Science Basics. Public Health Institute/Center for Climate Change, and Health.

Qi, Z., and Helmers, M. J. (2010). Soil water dynamics under winter rye cover crop in central Iowa. Vadose Zone J. 9, 53-60. doi: 10.2136/vzj2008.0163

Rao, K. P. C., Verchot, L. V., and Laarman, J. (2007). Adaptation to climate change through sustainable management and development of agroforestry systems. J. SAT Agric. Res. 4, 1-30. Available online at: http://oar.icrisat.org/id/eprint/2561

Reddy, P. P. (2016). Sustainable Intensification of Crop Production. Singapore: Springer, 143-154. doi: 10.1007/978-981-10-2702-4

Reij, C., Scoones, I., and Toulmin, C. (2013). Sustaining the Soil: Indigenous Soil and Water Conservation in Africa. Oxfordshire: Routledge. doi: $10.4324 / 9781315070858$

Risiro, J., Mashoko, D., Tshuma, T., and Rurinda, E. (2012). Weather forecasting and indigenous knowledge systems in Chimanimani district of Manicaland, Zimbabwe. J. Emerg. Trends Educ. Res. Policy Stud. 3, 561-566.

Robacer, M., Canali, S., Kristensen, H. L., Bavec, F., Mlakar, S. G., Jakop, M., et al. (2016). Cover crops in organic field vegetable production. Sci. Hortic. 208, 104-110. doi: 10.1016/j.scienta.2015.12.029

Rosenstock, T. S., Dawson, I. K., Aynekulu, E., Chomba, S., Degrande, A., Fornace, K., et al. (2019). A planetary health perspective on agroforestry in sub-saharan Africa. One Earth 1, 330-344. doi: 10.1016/j.oneear.2019.10.017
Ross, C. (2017). Ecology and power in the age of empire: Europe and the transformation of thetropical world. Oxford: Oxford University Press. doi: 10.1093/acprof:oso/9780199590414.001.0001

Sainju, U. M., Singh B. P., Whitehead, W. F., and Wang, S. (2006). Carbon supply and storage in tilled and nontilled soils as influenced by cover crops and nitrogen fertilization. J. Environ. Qual. 35, 1507-1517. doi: 10.2134/jeq2005.0189

Sammis, T., Sharma, P., Shukla, M., Wang, J., and Miller, D. (2012). A waterbalance drip irrigation scheduling model. Agric. Water Manag. 113, 30-37. doi: 10.1016/j.agwat.2012.06.012

Scalise, A., Pappa, V. A., Gelsomino, A., and Rees, R. M. (2017). Pea cultivar and wheat residues affect carbon/nitrogen dynamics in pea-triticale intercropping: a microcosms approach. Sci. Total Environ. 592, 436-450. doi: 10.1016/j.scitotenv.2017.03.012

Sharma, P., Singh, A., Kahlon, C. S., Brar, A. S., Grover, K. K., Dia, M., and Steiner, R. L. (2018). The role of cover crops towards sustainable soil health and agriculture-a review paper. Am. J. Plant Sci. 9, 1935-1951. doi: 10.4236/ajps.2018.99140

Sierra, J., Dulormne, M., and Desfontaines, L. (2002). Soil nitrogen as affected by Gliricidia sepium in a silvopastoral system in Guadeloupe, French Antilles. Agrofor. Syst. 54, 87987. doi: 10.1023/A:1015025 401946

Sileshi, G., Akinnifesi, F. K., Ajayi, O. C., Chakeredza, S., Kaonga, M., and Matakala, P. W. (2007). Contributions of agroforestry to ecosystem services in the Miombo eco-region of eastern and southern Africa. Afric. J. Environ. Sci. Technol. 1, 68-80.

Sileshi, G. W., Mafongoya, P. L., Akinnifesi, F. K., Phiri, E., Chirwa, P., Beedy, T., et al. (2014). "Agroforestry: fertilizer trees," in Encyclopedia of Agriculture and Food Systems (Amsterdam: Elsevier), 222-234. doi: 10.1016/B978-0-444-52512-3.00022-X

Simons, A. J., and Leakey, R. R. B. (2004). "Tree domestication in tropical agroforestry," in New Vistas in Agroforestry (Dordrecht: Springer), 167-181. doi: 10.1007/978-94-017-2424-1_12

Singh, B. B., Ajeigbe, H. A., Tarawali, S. A., Fernandez-Rivera, S., and Abubakar, M. (2003). Improving the production and utilization of cowpea as food and fodder. Field Crops Res. 84, 169-177. doi: 10.1016/S0378-4290(03) 00148-5

Singh, R., and Singh, G. S. (2017). Traditional agriculture: a climate-smart approach for sustainable food production. Energy Ecol. Environ. 2, 296-316. doi: 10.1007/s40974-017-0074-7

Soropa, G., Gwatibaya, S., Musiyiwa K., Rusere, F., Mavima, G. A., and Kasasa, P. (2015). Indigenous knowledge system weather forecasts as a climate change adaptation strategy in smallholder farming systems of Zimbabwe: case study of Murehwa, Tsholotsho and Chiredzi districts. Afr. J. Agric. Res. 10, 1067-1075. doi: 10.5897/AJAR2013.7205

Szott, L. T., Fernandes, E. C., and Sanchez, P. A. (1991). Soil-plant interactions in agroforestry systems. For. Ecol. Manage 45, 127-152. doi: 10.1016/0378-1127(91)90212-E

Theisen, G., Silva, J. J. C., Silva, J. S., Andres, A., Anten, N. P., and Bastiaans, L. (2017). The birth of a new cropping system: towards sustainability in the sub-tropical lowland agriculture. Field Crops Res. 212, 82-94. doi: 10.1016/j.fcr.2017.07.001

Thornton, P. K., Jones, P. G., Ericksen, P. J., and Challinor, A. J. (2011). Agriculture and food systems in sub-Saharan Africa in a $4^{\circ} \mathrm{C}$ world. Math. Phys. Eng. Sci. 369, 117-136. doi: 10.1098/rsta.2010.0246

Tomar, J. M. S., Ahmed, A., Bhat, J. A., Kaushal, R., Shukla, G., and Kumar, R. (2021). Potential and opportunities of agroforestry practices in combating land degradation. doi: 10.5772/intechopen.97843

Triberti, L., Nastri, A., and Baldoni, G. (2016). Long-term effects of crop rotation, manure and mineral fertilisation on carbon sequestration and soil fertility. Eur. J. Agron. 74, 47-55. doi: 10.1016/j.eja.2015.11.024

Ubisi, N. R., Kolanisi, U., and Jiri, O. (2019). The role of indigenous knowledge systems in rural smallholder farmers' response to climate change: case study of Nkomazi Local Municipality, Mpumalanga, South Africa. J. Asian Afric. Stud. 55, 273-284. doi: 10.1177/0021909619874824

Udawatta, R. P., Gantzer, C. J., and Jose, S. (2017). "Agroforestry practices and soil ecosystem services," in Soil Health and Intensification of Agroecosytems 
(New York: Academic Press), 305-333. doi: 10.1016/B978-0-12-805317-1. 00014-2

Uejio, C. K., Tamerius, J. D., Wertz, K., and Konchar, K. M. (2015). "Primer on climate science," in Global Climate Change and Human Health, eds G. Luber and J. Lemery (San Francisco, CA: Jossey-Bass), 5.

United States Environmental Protection Agency (2016). Inventory of US greenhouse gas emissions and sinks: 1990-2014 (DRAFT). Available online at: https://www3.epa.gov/climatechange/ghgemissions/gases.htm (accessed July 14, 2016).

Vanlauwe, B., Bationo, A., Chianu, J., Giller, K. E., Merckx, R., Mokwunye, U., et al. (2010). Integrated soil fertility management operational definition and consequences for implementation and dissemination. Outlook Agric. 39, 17-24. doi: $10.5367 / 000000010791169998$

Wang, L., Zheng, H., Wen, Z., Liu, L., Robinson, B. E., Li, R., et al. (2019). Ecosystem service synergies/trade-offs informing the supply-demand match of ecosystem services: framework and application. Ecosyst. Serv. 37:100939. doi: 10.1016/j.ecoser.2019.100939

Whitt, L. A. (1999). "Indigenous peoples, their environment and territories," in Cultural and Spiritual Values of Biodiversity, eds D. A. Posey (Nairobi: United Nations Environment Programme), 69-72.

Wick, A., Berti, M., Lawley, Y., and Liebig, M. (2017). "Integration of annual and perennial cover crops for improving soil health," in Soil Health and Intensification of Agroecosystems, M. A. Mahdi and B. Lowery (San Diego, CA: Academic Press), 127-150. doi: 10.1016/B978-0-12-805317-100006-3

Wortman, S. E., Drijber, R. A., Francis, C. A., and Lindquist, J. L. (2013). Arable weeds, cover crops, and tillage drive soil microbial community composition in organic cropping systems. Appl. Soil Ecol. 72, 232-241. doi: 10.1016/j.apsoil.2013.07.014

Zhang, J., Wang, L., Su, J. (2018). The soil water condition of a typical agroforestry system under the policy of Northwest China. Forests 9:730. doi: 10.3390/f9120730

Ziervogel, G., Cartwright, A., Tas, A., Adejuwon, J., Zermoglio, F., Shale, M., and Smith, B. (2008). Climate Change and Adaptation in African Agriculture. Stockholm: Stockholm Environment Institute, 17-19.

Conflict of Interest: The authors declare that the research was conducted in the absence of any commercial or financial relationships that could be construed as a potential conflict of interest.

Publisher's Note: All claims expressed in this article are solely those of the authors and do not necessarily represent those of their affiliated organizations, or those of the publisher, the editors and the reviewers. Any product that may be evaluated in this article, or claim that may be made by its manufacturer, is not guaranteed or endorsed by the publisher.

Copyright (c) 2021 Imoro, Imoro, Duwiejuah and Abukari. This is an open-access article distributed under the terms of the Creative Commons Attribution License (CC $B Y)$. The use, distribution or reproduction in other forums is permitted, provided the original author(s) and the copyright owner(s) are credited and that the original publication in this journal is cited, in accordance with accepted academic practice. No use, distribution or reproduction is permitted which does not comply with these terms. 